\title{
Retraction: Nonlinear Effects of Intellectual Property Rights on Technological Innovation
}

Selma Ezzeddine

Management and Economics, Sfax University, Sfax, Tunisia

M.Sami Hammami

Management and Economics, Sfax University, Sfax, Tunisia

The above article from Journal of Economic Integration, published on 1 June 2018, has been retracted because of plagiarism.

It turns out that the above article plagiarized the paper "Protection des droits de propriété intellectuelle et innovation technologique: Cas des pays émergents" presented at the 2013 ASECTU FORUM by Kamilia Loukil. 